\title{
OBSERVATIONS ON THE SHRINK TEMPERATURE OF COLLAGEN AND ITS VARIATIONS WITH AGE AND DISEASE
}

\author{
BY \\ PATRICIA C. BROWN, R. CONSDEN, AND L. E. GLYNN \\ Special Unit for Juvenile Rheumatism, Canadian Red Cross Memorial Hospital, Taplow, \\ near Maidenhead, Berkshire, England
}

The shrinkage temperature of collagen is related to its stability. When shrinkage takes place, it is thought that the hydrothermal agitation at this temperature is sufficient to overcome the forces, chiefly hydrogen bonds, which hold together the polypeptide chains. When stability is reduced by removal of hydrogen bonds with hydrogen bond breakers or by chemical damage, less energy is required to force the chains apart and so the shrink temperature is reduced. This is also paralleled by reduced resistance to the action of trypsin-like enzymes. Conversely, the introduction of new cross links into collagen, as in tanning, will increase enzyme resistance and the shrink temperature.

The different forms of collagen, soluble and insoluble, which occur together in native collagen, vary somewhat in their stability. Banga, Baló, and Szabó (1956) have suggested that the soluble has a stabilizing effect on the insoluble. In addition, polysaccharides and non-collagen proteins are concerned in the biogenesis of collagen fibres and their development into fully mature collagen (Bowes and Kenten, 1950; Partridge, 1948; Jackson, 1953). These constituents, always present in intimate association with native collagen, are probably important in determining the final stability and low turnover rate characteristic of fully mature collagen. It was therefore thought of interest to examine the shrink temperatures of human tissues of different ages to ascertain whether there were any age trends, and, if so, to correlate them with those changes in the various constituents which are known to take place with development and ageing. Further, since collagen in the uterus is rapidly deposited during pregnancy and rapidly absorbed after parturition (Harkness and Harkness, 1954), a feature which distinguishes this from collagen of other tissues and organs, the shrink temperature of uterine collagen from the uterus of various ages and in pregnancy was therefore of special interest.
In rheumatoid arthritis there is evidence, derived from electron microscopy, $x$-ray diffraction (Kell- iv gren, Ball, Astbury, Reed, and Beighton, 1951: Kellgren, 1952), and histological studies (Glynn and $\mathscr{\mathscr { C }}$ Reading, 1956), that collagen fibres have suffered damage. We therefore thought it desirable to $\rightarrow$ examine this and tissue from other "collagen disease" for any alteration in shrink temperature.

Much of the data on shrink temperature has been $\overrightarrow{0}$ derived from species other than man. Further many experiments have been carried out on such materials as hide powder which have probab become so altered as a result of preparation that the tissue finally examined could hardly be regarded as normal. Small but significant changes in shrink temperatures can occur after relatively mild treatments. Consequently, as far as untreated tissues $\overline{\overline{0}}$ were concerned, we considered it important to $\exists$ measure their shrink temperatures as soon as possible after collection, avoiding any pre-treatments such as washing, solvent extraction or prolonged storage. Also, since comparatively few observations have been made on human tissue, and since some of the data on non-human tissue are unreliable for reasons already mentioned and sometimes conflicting, a number of problems, such as the effect of hydrogen bond breakers were re-examined using 9 fresh human tissue. For a few experiments, animal tissue was also used.

We have chosen normal saline in which to measure shrink temperatures since this appeared to be appropriate physiologically. It was found that the $\triangle$ shrink temperature in saline was lower than that $\omega$ in water and was identical for different fibres in any given specimen. It was necessary to carry out 0 shrink temperature measurements in a micro- $\mathbb{\Phi}$ apparatus when dealing with biopsied tissue avail- $\stackrel{?}{?}$ able in only small amounts, and this method $\underset{T}{0}$ was used in most of the experiments described here. 


\section{Methods}

\section{(1) Shrink Temperature Measurement}

(a) Macro Method.-This method was used only for a few measurements in the earlier part of this work. A strip of tissue $1-1.5 \mathrm{~cm}$. was inserted into the lower end of a Westergren erythrocyte sedimentation rate tube. This was immersed in a beaker of water which was gradually heated. The temperatures at which the tissues started and finished shrinkage were recorded.

(b) Micro Method.-Small fibres teased out from the tissue immersed in physiological saline were allowed to rise up a capillary melting point tube, one end of which was then sealed. The tube and contents were placed in the micro-melting point apparatus (Gallenkamp) and the fibres observed under low magnification $(\times 60)$. By means of a rheostat in the circuit, the voltage applied across the heating element could be controlled up to a maximum of 6 volts. In this way, the heating was suitably controlled so that the rise of temperature was never greater than $2^{\circ} \mathrm{C}$. per minute. Temperatures at which fibres started and finished shrinking were recorded. These are designated $T s_{1}$ and $T s_{2}$ respectively, and Ts refers to the complete range of shrinkage $\left(T s_{1}\right.$ to $\left.T s_{2}\right)$. All temperatures are expressed in ${ }^{\circ} \mathrm{C}$.

\section{(2) Analyses}

(a) Nitrogen was estimated by the permanganate modification of the micro Kjeldahl method (Beet, 1955).

(b) Hydroxyproline was estimated in hydrolysates according to the method of Neuman and Logan (1950).

(c) Salicylate in extracts was determined by the method of Trinder (1954).

(d) Fluorescence in Ultra-Violet Light was observed macroscopically under the high-pressure mercury lamp (Hanovia Model XI) with Woods glass filter.

\section{(3) Materials}

(a) Tissues.-Human tissue obtained at autopsy or at operation was examined in most cases immediately after collection, and, occasionally after being kept overnight at $0-4^{\circ} \mathrm{C}$. Overnight storage at this temperature had no effect on the shrink temperature, whereas storage at $-20^{\circ} \mathrm{C}$. caused a lowering of as much as $4^{\circ} \mathrm{C}$. in the $\mathrm{Ts}_{1}$ of many of the specimens. Apart from uteri, dura mater or fascia lata were used in all comparative work, as in any one individual these had a similar shrink temperature, and, except where indicated, all tissues were from patients not suffering from any "collagen disease".

(b) Acid Soluble Collagen was prepared by salt precipitation of citrate extracts of rabbit skins, based on the method described by Bowes, Elliott, and Moss (1955).

\section{Results}

\section{Various Extraction Procedures}

(a) Effect of Hyaluronidase and Periodate on Ts.Rabbit fascia and tendon and rat fascia and tail tendon (kept overnight at $-20^{\circ} \mathrm{C}$.) were treated with hyaluronidase or periodate. For the former treatment the tissue was incubated at $37^{\circ} \mathrm{C}$. overnight in acetate buffer, $0 \cdot 1 \mathrm{M}, \mathrm{pH} 5 \cdot 2$, containing $1 \mathrm{mg}$. $/ \mathrm{ml}$. "Hyalase" (Benger). Controls consisted of tissue incubated in acetate buffer without hyalase. The tissue residues were washed three times with normal saline and then three times with water. For the periodate treatment the tissue was allowed to stand at room temperature for 17 hours in a solution of sodium periodate $(0.5$ per cent.) in acetate buffer $(0 \cdot 1 \mathrm{M}, \mathrm{pH} 4 \cdot 0)$. Controls were similarly treated in the acetate buffer without periodate. The Ts by the macro method, in water, is recorded in Table I, which demonstrates that those of the treated and control tissues were equally lowered by both treatments.

TABLE I

EFFECT OF HYALURONIDASE AND PERIODATE ON TS

\begin{tabular}{|c|c|c|c|c|c|c|c|c|}
\hline \multirow{2}{*}{\multicolumn{4}{|c|}{ Tissue }} & \multirow{3}{*}{$\begin{array}{c}\begin{array}{c}\text { Before } \\
\text { Treatment }\end{array} \\
67-70 \\
\end{array}$} & \multicolumn{2}{|c|}{ Hyaluronidase } & \multicolumn{2}{|c|}{ Periodate } \\
\hline & & & & & \multirow{2}{*}{$\begin{array}{c}\text { Treated } \\
58-64 \\
\end{array}$} & \multirow{2}{*}{$\begin{array}{c}\begin{array}{c}\text { Control } \\
\text { (Buffer only) }\end{array} \\
54-58 \\
\end{array}$} & \multirow{2}{*}{$\begin{array}{c}\text { Treated } \\
52-58 \\
\end{array}$} & \multirow{2}{*}{$\begin{array}{c}\begin{array}{c}\text { Control } \\
\text { (Buffer only) }\end{array} \\
52-60 \\
\end{array}$} \\
\hline Rabbit Fascia & . & . & .. & & & & & \\
\hline Rabbit Tendon & .. & . & .. & $62-66$ & $56-60$ & $56-60$ & $49-50$ & $47-50$ \\
\hline Rat Fascia .. & .. & . & 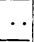 & $62-65$ & $54-57$ & $52-57$ & $52-54$ & $48-53$ \\
\hline Rat Tail Tendon & & $\ldots$ & .. & $63-66$ & $51-54$ & $47-52$ & $42-45$ & $40-44$ \\
\hline
\end{tabular}


(b) Effect of Buffers and Strong Alkali on Ts.Pieces of fascia from a stillborn child and from a 63-year-old man, which had been stored for some weeks in a frozen state, were immersed for 3 days at room temperature in water, $M / 15$ phosphate of $\mathrm{pH} \mathrm{7,} \mathrm{M/5} \mathrm{citrate} \mathrm{of} \mathrm{pH} 4$, and $\mathrm{M} / 5 \mathrm{KOH}$. It was noted that the $\mathrm{KOH}$-treated tissue was greatly swollen. The tissues were then washed three times with water and then three times with saline and the Ts was determined (Table II). The Ts figures of the water control in the adult specimen were slightly low because the tissue had been frozen. Only $\mathrm{KOH}$ treatment lowered the Ts, the effect on the young tissue being greater.

TABLE II

TS AFTER EXTRACTION WITH BUFFERS OR STRONG ALKALI

\begin{tabular}{|c|c|c|c|}
\hline \multirow{2}{*}{$\begin{array}{c}\text { Treatment of } \\
\text { Tissue }\end{array}$} & & \multicolumn{2}{|c|}{ Source of Tissue } \\
\hline & & Full-Term & Man Aged \\
\hline $\mathrm{H}_{2} \mathrm{O}$ Control $\ldots$ & $\cdots$ & $55-61$ & $58-65$ \\
\hline Phosphate pH 7.M/15.. & .. & $54-61$ & $58-65$ \\
\hline Citrate pH 4.M/5 & .. & $54-61$ & $57-65$ \\
\hline КОН M/5 & $\cdot$ & $41-52$ & $52-61$ \\
\hline
\end{tabular}

\section{Effect of Hydrogen Bond Breakers}

(a) Fascia Lata from One Individual.-The tissue was obtained at autopsy from a woman aged 25 (dying from cerebral haemorrhage due to malignant hypertension). Small pieces were immersed for 4 days at room temperature in solutions of various reagents of $2 \mathrm{M}$ strength except potassium phenol sulphonate which could not be made stronger than $1 \mathbf{M}$, water-saturated phenol, and phenolsaturated water. The solutions were about $\mathrm{pH} 7 \cdot 0$ to brom-thymol blue indicator. The tissues were washed three times with water and then three times with saline. The resulting shrink temperatures in saline by the micro method are recorded in Table III.

TABLE III

TS OF FASCIA LATA AFTER TREATMENT WITH VARIOUS REAGENTS

\begin{tabular}{|c|c|c|c|c|}
\hline \multicolumn{4}{|c|}{ Treatment of Tissue } & Ts $\left({ }^{\circ} \mathrm{C}.\right)$ \\
\hline 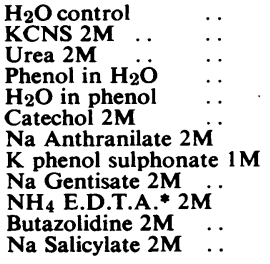 & $\begin{array}{l}\cdots \\
\cdots \\
\cdots \\
\cdots \\
\cdots \\
\cdots \\
\cdots \\
\cdots \\
\cdots \\
\cdots\end{array}$ & $\begin{array}{l}\cdots \\
\cdots \\
\cdots \\
\cdots \\
\cdots \\
\cdots \\
\cdots \\
\cdots\end{array}$ & $\begin{array}{l}\cdots \\
\cdots \\
\cdots \\
\cdots \\
\cdots \\
\cdots \\
\cdots \\
\cdots \\
\cdots \\
\cdots\end{array}$ & $\begin{array}{l}61-66 \\
57-64 \\
52-66 \\
62-66 \\
35-63 \\
62-71 \\
59-66 \\
62-66 \\
37-63 \\
60-65 \\
56-66 \\
32-62\end{array}$ \\
\hline
\end{tabular}

* Ethylene diamine tetra acetate.

After salicylate, the tissue appeared somewhat swollen in contrast to the other tissues. The greatest fall in Ts was obtained with salicylate, $\mathscr{\odot}$ gentisate, and water-saturated phenol ( $p$-amino $ᄋ$ salicylate was equally effective, see below).

(b) Fascia Lata of Individuals of Different Ages.Tissues were all obtained at autopsy from patients $\overparen{D}$ who had not suffered from any connective tissue $\vec{\bullet}$ disease. Treatment in various reagents was carried of out as described above and the results are shown 通 Table IV. From these results we draw the following conclusions:

(i) The older the tissue the higher the Ts appears to be.

(ii) The Ts of the younger tissue is lowered to a greater extent by all the hydrogen bond breakers, $\overline{\bar{o}}$ and, even those reagents without effect on the $\exists$ older specimens still had a distinct effect on the younger tissues.

(iii) Salicylate and p-amino-salicylate lowered the Ts most.

\section{Salicylate Experiments}

(a) Variation of Ts with Salicylate Concentration. -Fascia lata from a 15-year-old girl who had died

TABLE IV

TS AFTER TREATMENT WITH HYDROGEN BOND BREAKERS OF FASCIA LATA FROM INDIVIDUALS OF VARIOUS AGES

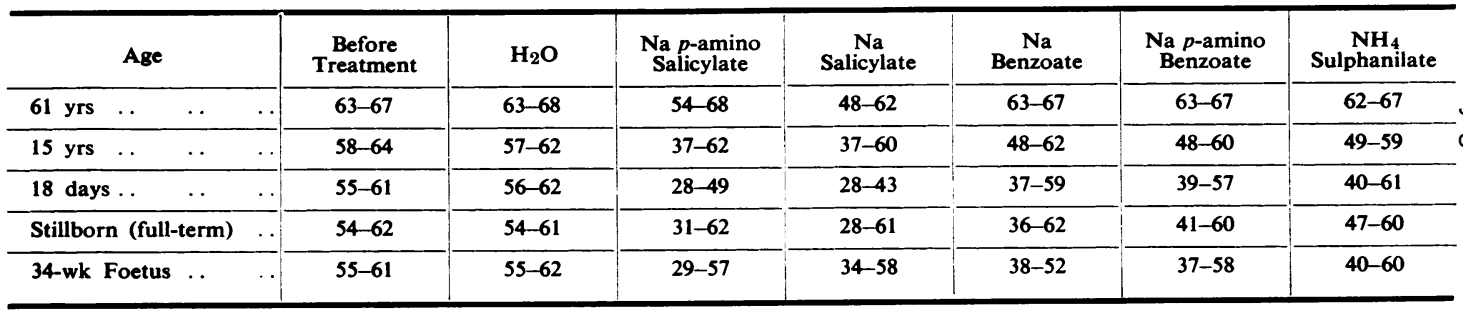


from Schönlein-Henoch purpura and glomerulonephritis was treated in doubling dilutions of sodium salicylate starting with $2 \mathrm{M}$ for 4 days at room temperature. Shrink temperatures were determined after washing (as described above); the results are recorded in Fig. 1. Up to a concentration of $0.5 \mathrm{M}$ there was no lowering of Ts. At higher concentrations there was a rapid fall of $T s_{1}$.

(b) Variation of Ts with Incubation Temperature.The tissue was the same as that described in $\operatorname{II}(a)$. Samples were kept in $2 \mathrm{M}$ salicylate for 4 days at $4^{\circ}, 18^{\circ}, 37^{\circ}$, and $56^{\circ} \mathrm{C}$. The results are shown in Table V. The lowering was less at $4^{\circ}$ than at $18^{\circ} \mathrm{C}$. and those tissues treated at higher temperatures began shrinking at temperatures above those of the treatment.

(c) Effect of Acid Treatment of Salicylate-Treated Tissue.-The Ts of rabbit acid soluble collagen

TABLE V

VARIATION OF TS WITH TEMPERATURE OF SALICYLATE TREATMENT (2M)

\begin{tabular}{c|c|c}
\hline $\begin{array}{c}\text { Temperature of } \\
\text { Treatment }\end{array}$ & $\begin{array}{c}\text { Ts after 2M } \\
\text { Salicylate }\end{array}$ & $\begin{array}{c}\text { Ts of } \mathrm{H}_{2} \mathrm{O} \\
\text { Control }\end{array}$ \\
\hline $4^{\circ} \mathrm{C}$. & $52-62$ & $61-66$ \\
\hline $18^{\circ} \mathrm{C}$. & $33-62$ & $61-66$ \\
\hline $37^{\circ} \mathrm{C}$. & $38-56$ & $62-66$ \\
\hline $56^{\circ} \mathrm{C}$. & $56-61$ & $62-66$ \\
\hline
\end{tabular}

was observed to be $41-45^{\circ} \mathrm{C}$. Since $2 \mathrm{M}$ salicylate lowered the Ts to this or lower figures, the following experiment was carried out to determine whether salicylate-treated tissue was similar in any other way to acid soluble collagen.

Fascia from an 18-day-old infant (initial Ts 55-61 ${ }^{\circ} \mathrm{C}$.) which after treatment with $2 \mathrm{M}$ salicylate for 4 days had Ts $28-41^{\circ} \mathrm{C}$., was then shaken with $\mathrm{M} / 5$ citrate buffer $\mathrm{pH}$ 4. After extraction, the Ts was raised to $34-48^{\circ} \mathrm{C}$. The citrate supernatant was made alkaline with $\mathrm{KOH}$, but there was no precipitate.

Acid soluble rabbit collagen (Ts $41-45^{\circ}$ C.) dissolved readily and completely in $2 \mathrm{M}$ salicylate at room temperature. The solution was left at this temperature for 4 days, dialysed against distilled water, and made alkaline with $\mathrm{KOH}$. No precipitation occurred. When another sample of acid soluble collagen was dissolved in citrate buffer, dialysed and made alkaline, it was re-precipitated.

(d) To Test whether the Salicylate Effect on Ts was due to Swelling

(i) Effect of High Concentrations of Neutral Salts on the Ts of Salicylate-Treated Tissue.-In one experiment, tissue which had been treated with $2 \mathrm{M}$ salicylate was washed with water. One portion was then treated with $2 \mathrm{M} \mathrm{CaCl}_{2}$ solution for 4 days at room temperature, and another with saturated $\mathrm{NaCl}$. Controls were tissues which were given the calcium chloride and sodium

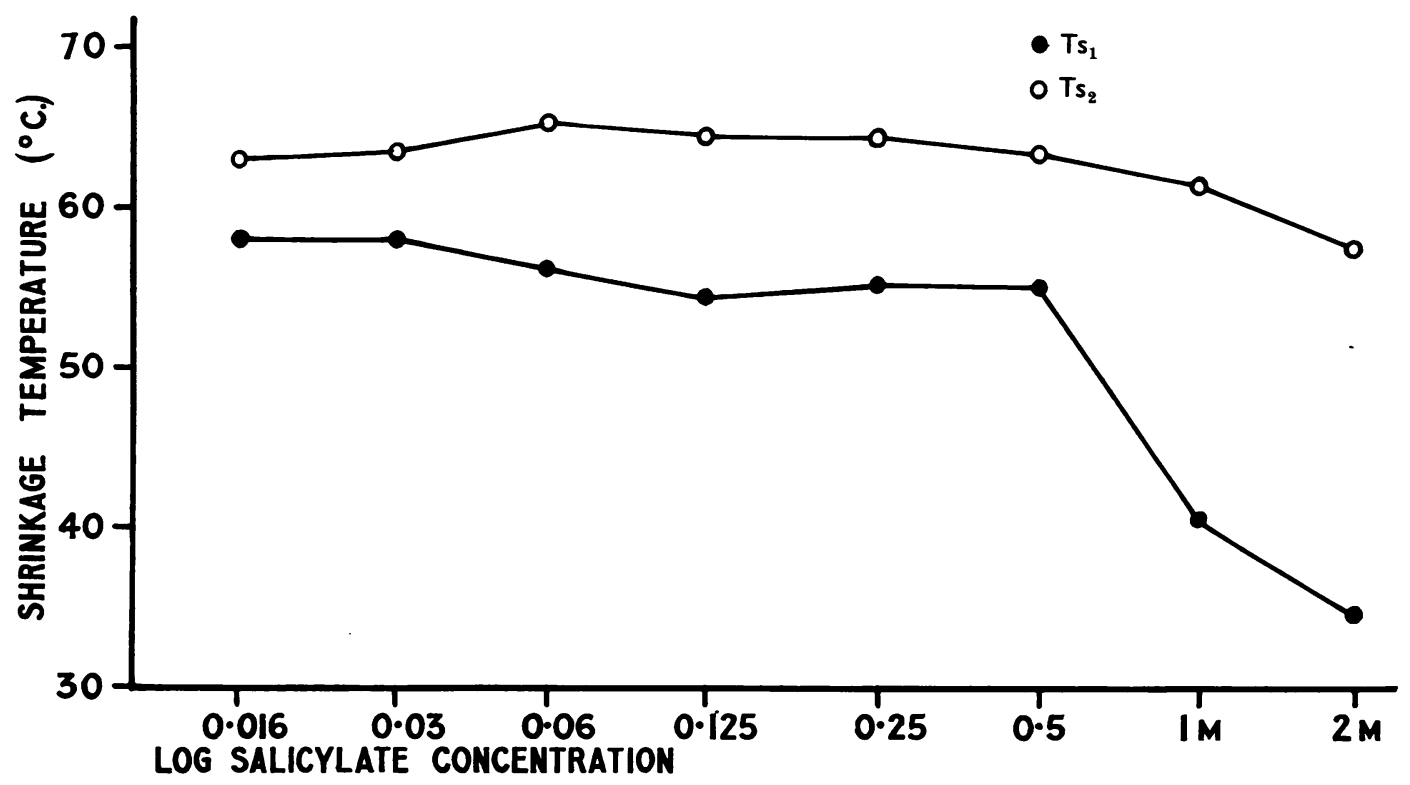

Fig. 1.-Variation of Ts with concentration of salicylate used in pre-treatment. 
chloride treatments only. Shrinkage temperatures were measured after washing (Table VI).

TABLE VI

EFFECT OF NEUTRAL SALTS ON TS OF SALICYLATE TREATED AND CONTROL TISSUES

\begin{tabular}{l|l|c|c}
\hline \multicolumn{1}{c|}{ Salt Solution } & $\begin{array}{c}\text { Tissue Treated with } \\
\text { Salicylate (Ts 33-62) }\end{array}$ & $\begin{array}{c}\text { Tissue not Treated } \\
\text { with Salicylate } \\
\text { (Ts 54-64) }\end{array}$ \\
\hline Saturated NaCl & $29-63$ & $55-62$ \\
\hline $\mathrm{CaCl}_{2}$ 2M $\ldots$ & $27-64$ & $54-60$ \\
\hline
\end{tabular}

Tissue (Ts 51-60 C.) was treated with $2 \mathrm{M}$ salicylate alone and $2 \mathrm{M}$ salicylate containing 10 per cent. $\mathrm{NaCl}$ for 4 days. There was little difference in the appearance of both specimens. The Ts after each treatment was identical $\left(27-53^{\circ}\right.$ C.).

These experiments indicate that the presence of strong solutions of electrolytes, which prevent the uptake of water molecules, have little effect on the lowering of Ts by salicylate, and that treatment with strong salt solutions does not lower the Ts of fresh tissue.

(ii) Water Content of Tissue before and after Salicylate Treatment.-Three samples of tissues were treated in distilled water $1 \mathrm{M}$ and $2 \mathrm{M}$ salicylate respectively. After treatment the tissues were washed with water, lightly blotted with filter paper, and weighed. They were then reweighed after drying in vacuo over $\mathrm{MgClO}_{4}$. The amount of water in the salicylate-treated tissue was calculated from the increase in weight less the absorbed salicylate. $^{*}$ The results are recorded in Table VII. The amount of water present in salicylate-treated tissue is similar to that present in untreated tissue.

$$
\text { TABLE VII }
$$

WATER CONTENT OF SALICYLATE TREATED TISSUE COMPARED WITH UNTREATED TISSUE

\begin{tabular}{c|c|c|c}
\hline $\begin{array}{c}\text { Concentration } \\
\text { of Salicylate }\end{array}$ & $\begin{array}{c}\text { Loss of } \\
\text { Weight } \\
\text { on Drying } \\
\text { (per cent.) }\end{array}$ & $\begin{array}{c}\text { Estimated } \\
\text { Salicylate } \\
\text { Present } \\
\text { (per cent.) }\end{array}$ & $\begin{array}{c}\text { Water expressed } \\
\text { as Percentage } \\
\text { of Salicylate-free } \\
\text { Wet Tissue }\end{array}$ \\
\hline 0 & 79 & 0 & 79 \\
\hline $1 \mathrm{M}$ & 76 & 13 & 79 \\
\hline $2 \mathrm{M}$ & 73 & 40 & 81 \\
\hline
\end{tabular}

(e) Measurement of Ts in Solutions of Various Concentrations of Salicylate and Potassium Thiocyanate.-In these experiments, fibres from fresh tissue (Ts $61-67^{\circ}$ C.) were immersed and shrunk immediately in these solutions. Doubling dilutions of salicylate and thiocyanate from $2 \mathrm{M}$ to $0.0078 \mathrm{M}$ were used. The latter reagent was chosen because,

\footnotetext{
* The latter figure was obtained on the same tissue in a later
} experiment (Table VIII). by comparison with salicylate under the standard conditions already described (II $a$ ), it had much less effect on Ts. In addition the tissues were left in the salicylate solutions for 5 days at room temperature before measuring Ts in these solutions. The results are shown in Fig. 2 (opposite) from which the following observations can be made:

(i) Under these conditions salicylate lowers the Ts much more than thiocyanate.

(ii) When treated with $2 \mathrm{M}$ salicylate for 5 days, the $\mathrm{Ts}_{1}$ determined in saline dropped from 61 to $38^{\circ} \mathrm{C}$., whilst $\mathrm{Ts}_{2}$ remained at $67 \mathrm{C}$.; under the present conditions the same effect on $\mathrm{Ts}_{1}$ was produced by $0.5 \mathrm{M}$ salicylate, and $\mathrm{Ts}_{2}$ began falling in $0 \cdot 125 \mathrm{M}$ and continued to fall in increasing concentrations of salicylate.

(iii) In the 5-day salicylate-treated tissue, $\mathrm{Ts}_{1}$ was further decreased considerably but Ts., was not further affected.

(f) Action of Trypsin on Salicylate-Treated Tissue. - Two samples of dura mater from a male aged 63 were dried in vacuo over magnesium perchlorate and treated with $2 \mathrm{M}$ and $1 \mathrm{M}$ salicylate respectively for 4 days at room temperature. A third sample was similarly treated with distilled water. The tissues were then removed and washed with watero and the washings were added to their respective supernatants and made up to a suitable volume fo analysis. The tissues were then dried, and weighed amounts were incubated with trypsin (Armour 2,820 units $/ \mathrm{mg}$.) $1 \mathrm{mg}$. $/ \mathrm{ml}$. in 0.9 per cent. sodium bicarbonate or with bicarbonate alone at $37 \mathrm{C}$. for 17 hours. After washing as above, supernatants and washings were combined and made to volume. Residues were dried in vacuo. Analyses $(\mathrm{N}$, hydroxyproline, salicylate) were carried out according to the scheme set out below (all weighings were dry weights):

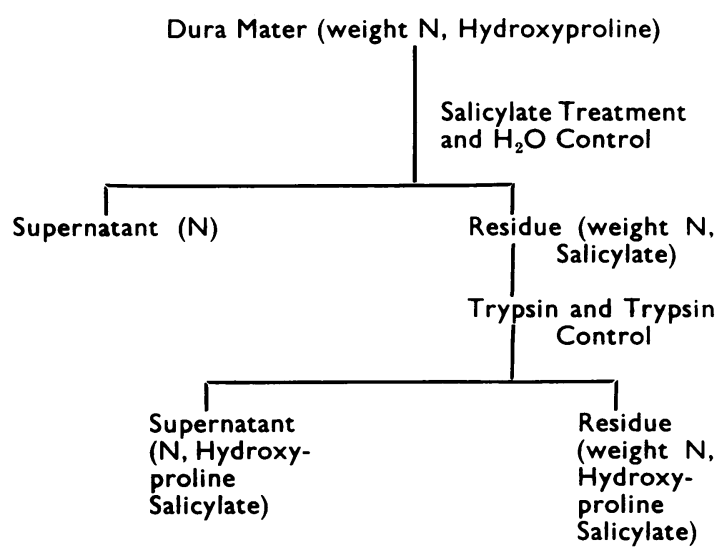
Residue (weight $\mathrm{N}$ 


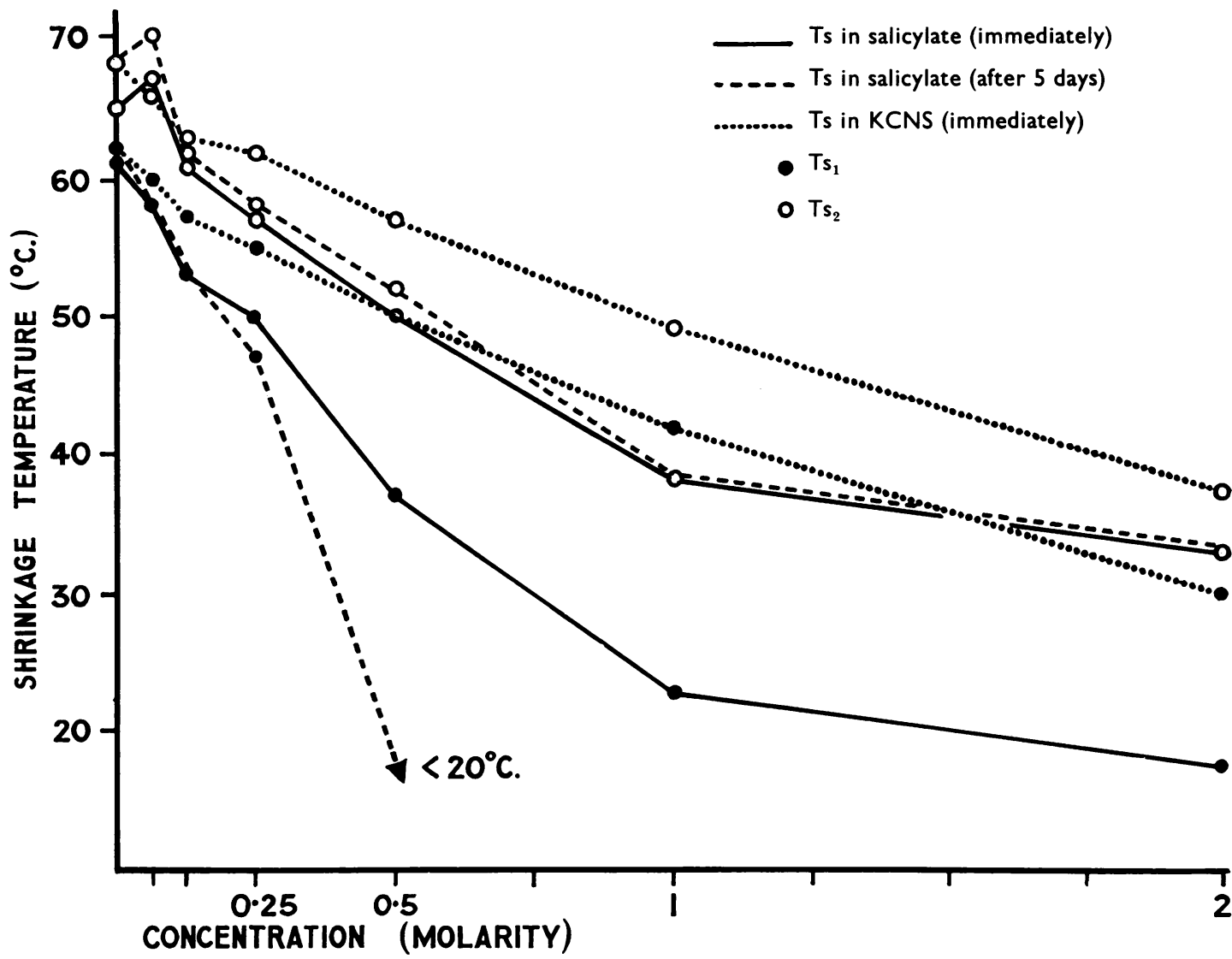

Fig. 2.-Ts in solutions of various concentrations of salicylate and thiocyanate.

The results are given in Table VIII. The salicylate recovered was calculated from the increase of dry weight of tissue after treatment, allowing for the protein extracted. The latter figure was computed from the nitrogen in the salicylate extract, using the conversion factor of $6 \cdot 25$. The nitrogen figures were probably somewhat low because of the presence of large amounts of salicylate which required pro-

TABLE VIII

ACTION OF TRYPSIN ON SALICYLATE-TREATED TISSUE

\begin{tabular}{|c|c|c|c|c|c|c|c|c|c|c|c|c|c|c|c|}
\hline \multirow{4}{*}{$\begin{array}{l}\text { Concen- } \\
\text { tration }\end{array}$} & \multicolumn{3}{|c|}{ Salicylate Treatment } & \multicolumn{7}{|c|}{ Trypsin Treatment of Salicylate-Treated Tissue } & \multicolumn{5}{|c|}{ Control (Buffer Alone) } \\
\hline & \multirow{3}{*}{ Ts } & \multirow{3}{*}{$\begin{array}{l}\text { Per } \\
\text { cent. } \\
\text { Weight } \\
\text { Change }\end{array}$} & \multirow{3}{*}{$\begin{array}{l}\text { Per } \\
\text { cent. } \\
\text { N } \\
\text { Loss }\end{array}$} & \multirow{3}{*}{ Ts } & \multirow{3}{*}{$\begin{array}{c}\text { Per } \\
\text { cent. } \\
\text { Weight } \\
\text { Loss }\end{array}$} & \multirow{3}{*}{$\begin{array}{l}\text { Per } \\
\text { cent. } \\
\mathbf{N} \\
\text { Loss }\end{array}$} & \multicolumn{3}{|c|}{ Hydroxyproline } & \multirow{3}{*}{$\begin{array}{c}\text { Per } \\
\text { cent. } \\
\text { Sali- } \\
\text { cylatet } \\
\text { Ex- } \\
\text { tracted }\end{array}$} & \multirow{3}{*}{$\begin{array}{c}\text { Per } \\
\text { cent. } \\
\text { Weight } \\
\text { Loss }\end{array}$} & \multirow{3}{*}{$\begin{array}{c}\text { Per } \\
\text { cent. } \\
\mathbf{N} \\
\text { Loss }\end{array}$} & \multicolumn{2}{|c|}{$\begin{array}{l}\text { Hydroxy- } \\
\text { proline }\end{array}$} & \multirow{3}{*}{$\begin{array}{c}\text { Per } \\
\text { cent. } \\
\text { Sali- } \\
\text { cylate† } \\
\text { Ex- } \\
\text { tracted }\end{array}$} \\
\hline & & & & & & & \multirow{2}{*}{\begin{tabular}{|c|} 
Per \\
cent. \\
Loss
\end{tabular}} & \multicolumn{2}{|c|}{$\begin{array}{l}\mathbf{N} \text { as per cent } \\
\text { total } \mathbf{N} \text { in }\end{array}$} & & & & \multirow{2}{*}{$\begin{array}{c}\text { Per } \\
\text { cent. } \\
\text { Loss }\end{array}$} & \multirow{2}{*}{\begin{tabular}{|}
$\mathbf{N}$ as \\
per cent. \\
Total \\
$\mathbf{N}$ in \\
Super- \\
natant
\end{tabular}} & \\
\hline & & & & & & & & $\begin{array}{l}\text { Resi- } \\
\text { due }\end{array}$ & $\begin{array}{l}\text { Super- } \\
\text { natant* }\end{array}$ & & & & & & \\
\hline $\mathbf{0}$ & $60-66$ & -15 & $5 \cdot 9$ & $60-66$ & 14 & $10 \cdot 6$ & $<0.01$ & $7 \cdot 9$ & $<0.01$ & - & 10 & $2 \cdot 3$ & $<0.01$ & $<0.01$ & - \\
\hline $1 M$ & $52-66$ & $+9 \cdot 5$ & $1 \cdot 7$ & $\overline{56-64}$ & 27 & $21 \cdot 0$ & $0 \cdot 78$ & $8 \cdot 3$ & $0 \cdot 28$ & 72 & 16 & $2 \cdot 4$ & $<0.01$ & $<0.01$ & 96 \\
\hline $2 M$ & $40-66$ & +39 & 0.9 & $43-64$ & 71 & $56 \cdot 5$ & 47 & $7 \cdot 0$ & $4 \cdot 34$ & 82 & 28 & $4 \cdot 4$ & $0 \cdot 74$ & 0.84 & 69 \\
\hline
\end{tabular}

- For the untreated tissue the value was $6 \cdot 6$.

+ Expressed as per cent. of that calculated to be present in the tissue after salicylate treatment (see Table VII). 
longed digestion and relatively large amounts of permanganate for clearing in the Kjeldahl procedure. The figures for salicylate are therefore considered to be approximate.

The following conclusions can be drawn from the data in Tables VII and VIII:

(i) Considerable amounts of salicylate remained on the tissue despite repeated washings, but most was extracted under the weak alkaline conditions of incubation. (It was found subsequently that substantially all salicylate could be extracted by prolonged ( 10 days) treatment with 0.9 per cent. bicarbonate at $37^{\circ}$ C.) Salicylate therefore comprised most of the material extracted by the solutions in the trypsin control experiments and formed about one-third of that dissolved out by trypsin.

(ii) Salicylate alone extracted small amounts of nitrogen, but progressively less with increasing concentration of salicylate.

(iii) The untreated tissue contained about 80 per cent. collagen as calculated from hydroxyproline content, assuming 8.2 hydroxyproline $\mathrm{N}$ as percentage of total nitrogen for collagen. Therefore, about 20 per cent. of the tissue was non-collagen protein, and this, after $1 \mathrm{M}$ salicylate, was completely removed by trypsin as compared with only half removed by trypsin acting on the tissue which had had no salicylate. The hydroxyproline data indicate that the 20 per cent. protein extracted from the $1 \mathrm{M}$ salicylate-treated tissue by the trypsin contained very little collagen. Trypsin following $2 \mathrm{M}$ salicylate extracts much more nitrogen than after $1 \mathrm{M}$ pre-treatment and this further nitrogen appeared to be derived from the collagen itself.

(iv) In bicarbonate alone, twice as much nitrogen was extracted from tissue treated with $2 \mathrm{M}$ salicylate than from untreated tissue or from that treated with $1 \mathrm{M}$ salicylate (4 per cent. compared with 2 per cent.). Also 10 per cent. of the bicarbonate extract after $2 \mathrm{M}$ salicylate was collagen and this represented 0.7 per cent. of the original collagen in the tissue. (v) Digestibility was not due to the shrinking of the collagen during the course of incubation. It does not appear likely that prolonged incubation caused shrinkage to occur at a lower temperature and therefore digestion to take place, since the residue after trypsin still had a similar low $\mathrm{Ts}_{\mathbf{1}}$.

\section{Tissues of Different Ages}

(a) Variation of $T s$ with Age and the Effect of Salicylate.-Shrink temperatures in saline were $\stackrel{\mathbb{Q}}{\varrho}$ determined by the micro method. The samples in were then treated with $2 \mathrm{M}$ salicylate as already described, and the Ts of the washed tissue was again determined in saline. These results are recorded in Table IX. (Ts $\mathbf{s}_{2}$ after salicylate treatment is not recorded, since it was unaltered in about half the cases and in the remainder, with the exception of an 18-day-old infant, the fall was around $4^{\circ} \mathrm{C}$.) By statistical analysis of some of the data for $T s_{1}$ of the untreated tissues, the variance ratio, $F$, between $\mathscr{\mathscr { C }}$ the groups $=35 \cdot 3$ : standard error for $T_{s_{1}}$ (single 을 determination) $=1 \cdot 33$; the least significant difference of the means between groups $=1.43(p=0.05)$ for $c$ means of seven determinations in each group and is correspondingly less where the number in a group is greater than seven. For the $\mathrm{Ts}_{1}$ of the salicylate treated tissues, $F$ between groups $=12.0$; standarg error (single determination) $=4 \cdot 17$; least significa difference of the means between groups of seven $\frac{0}{3}$ $4 \cdot 49$, between groups of seven and eight $=4 \cdot 36$, and between groups of eight and eighteen $=3 \cdot 57$. From these results the following conclusions may be drawn:

(i) Except between the age groups 15-25 and 26-44 years, the difference of means between groups is greater than 1.43 , and it may be concluded therefore that in any two age groups, with the exception of those mentioned above, the $\mathrm{Ts}_{1}$ is significantly higher in the older group. The $\mathrm{Ts}_{2}$ figures clearly follow the same pattern and the same conclusions would apply.

(ii) The statistical analysis of the $\mathrm{Ts}_{\mathbf{1}}$ salicylate

TABLE IX

VARIATION OF TS WITH AGE AND EFFECT OF SALICYLATE

\begin{tabular}{|c|c|c|c|c|c|c|c|c|}
\hline \multirow{2}{*}{\multicolumn{2}{|c|}{ Age Group }} & \multicolumn{2}{|c|}{$\mathbf{T s}_{1}$} & \multicolumn{2}{|c|}{ Ts2 } & \multicolumn{2}{|c|}{ Ts1 after Salicylate } & \multirow{2}{*}{ No. of Cases } \\
\hline & & Mean & Range & Mean & Range & Mean & Range & \\
\hline Foeti $12-40$ wks & $\cdots$ & $54 \cdot 4$ & $53-55$ & 60 & $59-62$ & $28 \cdot 7$ & $24-34$ & 7 \\
\hline $0-14$ yrs & $\cdots$ & $57 \cdot 7$ & $55-59$ & $63 \cdot 9$ & $61-67$ & $29 \cdot 8$ & $28-33$ & 12 \\
\hline $15-25$ yrs & .. & $59 \cdot 8$ & $57-62$ & $65 \cdot 7$ & $64-68$ & $31 \cdot 1$ & $27-37$ & 7 \\
\hline $26-44$ yrs & $\cdots$ & $59 \cdot 1$ & $57-61$ & $66 \cdot 2$ & $65-67$ & $35 \cdot 3$ & $32-47$ & 8 \\
\hline $45-88$ yrs & .. & $61 \cdot 2$ & $59-63$ & 67 & $66-68$ & $38 \cdot 5$ & $30-48$ & 18 \\
\hline
\end{tabular}


figures show that, although the increase from one age group to the next was not large enough to reach the 5 per cent. significance level, there was a steady increase with age, and this overall increase is highly significant $(F=12 \cdot 0)$.

(b) Examination of Uteri.-The Ts of uterine collagen was examined before and after $2 \mathrm{M}$ salicylate treatment as in the previous section (Table X). The fibres examined were teased out from the myometrium of the body of the uterus. Of the age group below 45 years, one was aged 4 months and the remainder from 25-45 years, four of which were pregnant. Statistical analysis of the $T s_{1}$ of untreated tissue gave the variance ratio $F=14 \cdot 41$, standard error of $T s_{1}=1 \cdot 74$, and the least significant difference $=1 \cdot 37$ for $p=0 \cdot 05$. The standard error of the $T s_{1}$ salicylate figures for a single determination was $2 \cdot 46$.

The following conclusions were drawn:

(i) In the untreated tissue there appeared to be little variation of $\mathrm{Ts}_{1}$ within each group but statistical analysis showed that the $\mathrm{Ts}_{1}$ means differed in a highly significant way between the two groups. $\mathrm{Ts}_{\mathbf{2}}$ did not vary significantly between the groups.

(ii) By comparison with the data in Table IX, collagen from the uterus up to about the age of the menopause is seen to be closely similar, as regards hydrothermal stability, to foetal collagen. Uterine collagen of the older group, on the other hand, resembled the 0 to 14 -yearold collagen.

(iii) After salicylate treatment the means between the two age groups of the $T s_{1}$ were not significantly different.

(c) Fluorescence and Age.-All tissues examined in the previous two sections were examined in ultraviolet light for fluorescence. No fluorescence was observed in any of the tissue from foeti or stillbirths. The only two samples obtained within the first year of life (4 and 11 months) fluoresced a weak purple. All the other tissues (4-year-old and over) fluoresced a brilliant white blue. This early manifestation of fluorescence in dura and fascia lata is not a feature of uterine collagen. Of the twelve uterine specimens under 45 years of age, eight between the ages of 25-45, of whom four were pregnant, did not fluoresce, two (aged 4 months and 41 years) fluoresced a weak purple, and two (aged 44 and 45 years) a brilliant white-blue. All sixteen specimens of over 45 years of age also fluoresced brilliantly. The failure to fluoresce by the younger uteri was not due to quenching by other protein, since digestion with trypsin left a residue which was still non-fluorescent and which showed no alteration of Ts. Trypsin digestion of a fluorescent tissue did not affect its fluorescence or Ts.

\section{Pathological Tissue}

(a) Rheumatoid Nodules.-Three specimens which were histologically typical rheumatoid nodules were obtained at biopsy. They consisted of a capsular area surrounding a tough white fibrous region in which were yellow necrotic foci. Fibres from these three areas were individually examined for $T s$, Ts after salicylate, and fluorescence (Table XI, overleaf). Different fibres from each area gave consistently repeatable readings.

From these results the following conclusions may be drawn:

(i) In general, fibres from any one area of one nodule behaved similarly to fibres from the same area of the other nodules, but there were significant differences between each of the three areas.

(ii) In the capsular area, the Ts of two were similar to the normal values of that age group (Table IX); the third was somewhat low. Salicylate produced a greater fall in $T s_{1}$ as compared with normal and, in contrast with normal tissue, $\mathrm{Ts}_{2}$ was also lowered.

(iii) The greatest changes occurred in the tough fibrous area; the $\mathrm{Ts}_{1}$ was lower even than that of the foetal group (Table IX), and the Ts, was lower than that of the capsular area. After salicylate, two had very low $\mathrm{Ts}_{1}$ and that of the third was raised, and in view of the very small amount of shrinkage, the significance of these results is not clear.

TABle X

TS OF HUMAN UTERI BEFORE AND AFTER 2M SALICYLATE

\begin{tabular}{|c|c|c|c|c|c|c|c|c|}
\hline \multirow{2}{*}{\multicolumn{2}{|c|}{ Age (yrs) }} & \multicolumn{2}{|c|}{ Ts $_{1}$} & \multicolumn{2}{|c|}{$\mathrm{Ts}_{2}$} & \multicolumn{2}{|c|}{ Ts 1 after Salicylate } & \multirow{2}{*}{ No. of Cases } \\
\hline & & Mean & Range & Mean & Range & Mean & Range & \\
\hline Under $45^{*}$ & . & $55 \cdot 2$ & $53-57$ & $63 \cdot 4$ & $61-67$ & $32 \cdot 1$ & $28-35$ & 12 \\
\hline Over 45 & .. & $57 \cdot 8$ & $55-61$ & $63 \cdot 1$ & $61-67$ & $32 \cdot 5$ & $28-36$ & 16 \\
\hline
\end{tabular}

* Full term of pregnancy in four cases. 
TABLE XI

Ts OF RHEUMATOID NODULES BEFORE AND AFTER 2M SALICYLATE AND PRESENCE OF FLUORESCENCE

\begin{tabular}{|c|c|c|c|c|c|c|c|c|c|}
\hline \multirow{2}{*}{ Nodule } & \multicolumn{3}{|c|}{ Capsular } & \multicolumn{3}{|c|}{ Tough Fibrous } & \multicolumn{3}{|c|}{ Yellow Necrotic } \\
\hline & Fluorescence & Ts & $\begin{array}{l}\text { Ts after } \\
\text { Salicylate }\end{array}$ & Fluorescence & Ts & $\begin{array}{c}\text { Ts after } \\
\text { Salicylate }\end{array}$ & Fluorescence & Ts & $\begin{array}{l}\text { Ts after } \\
\text { Salicylate }\end{array}$ \\
\hline I (age 46) & $\begin{array}{l}\text { Brilliant } \\
\text { white-blue }\end{array}$ & $58-64$ & $34-58$ & $\begin{array}{l}\text { Weak purple } \\
\text { purpen }\end{array}$ & $51-61$ & $57-61^{*}$ & $\begin{array}{c}\text { Very weak } \\
\text { purple }\end{array}$ & $54-64$ & $43-61 *$ \\
\hline II (age 49) & $\begin{array}{l}\text { Brilliant } \\
\text { white-blue }\end{array}$ & $60-66$ & $30-60$ & $\begin{array}{l}\text { Weak } \\
\text { purple }\end{array}$ & $52-64$ & $31-59 *$ & $\begin{array}{l}\text { Weak } \\
\text { white-blue }\end{array}$ & $55-60$ & $36-60^{*}$ \\
\hline III (age 55) & $\begin{array}{l}\text { Brilliant } \\
\text { white-blue }\end{array}$ & $60-67$ & $28-63$ & $\begin{array}{c}\text { Very weak } \\
\text { purple }\end{array}$ & $53-61$ & $28-55^{*}$ & $\begin{array}{l}\text { Very weak } \\
\text { purple }\end{array}$ & $55-65$ & $55-65^{*}$ \\
\hline
\end{tabular}

* Very little shrinkage.

(iv) The fibres from the yellow necrotic area had a Ts similar to that of foetal tissue and appeared to be intermediate in this respect between the capsular and tough fibrous areas. After salicylate the results again, as with the tough fibrous area, were difficult to assess.

(v) Whereas the capsular area fluoresced brilliantly like normal non-foetal fascia, all fibres from the other two areas fluoresced only very weakly.

(b) Fascia from Rheumatoid and Other "Collagen" Diseases.-Samples of fascia were obtained at operation or at autopsy from twelve cases of rheumatoid arthritis, two cases of rheumatic fever, one case of dermatomyositis, and one case of periarteritis nodosa. Shrinkage temperature before and after salicylate are recorded in Table XII. All these specimens showed the normal brilliant whiteblue fluorescence.

Because of the small number of samples, no statistical analysis has been attempted. In general, all the tissues appeared to be similar to the normal tissues (Table IX). However, in two cases, one of rheumatoid arthritis and one of rheumatic fever, the $\mathrm{Ts}_{2}, 71^{\circ}$ and $72^{\circ} \mathrm{C}$. respectively, was much higher than that of any other tissues examined. Both tissues were obtained at biopsy; the former patient was receiving penicillin 300,000 units twice a day and the latter was receiving salicylates.

\section{Discussion}

Shrink Temperature and Stabilizing Cross Linkage. - Several types of cross-link are theoretically available to account for the thermal stability of collagen, but it is doubtful whether the majority of these contribute to any great extent. Gustavson (1956a) divides these linkages into directed and non-directed, and of the directed linkages the most important are salt links and hydrogen bonds. Disruption of thê salt links by $\beta$-naphthol sulphonic acid reduces the Ts by only 14-16 C. (Gustavson, 1956b), whereas powerful hydrogen bond breakers, such as salFcylate, reduce it by as much as $30^{\circ} \mathrm{C}$. From this simple computation, it would appear that hydrogen bonds are of much greater importance than salt linkages. The virtual absence of thio-amino acids from collagen excludes the possibility of sulphur bridges playing any significant role. The presence of ester and other linkages has been suggested, but here again, on purely numerical grounds, these are unlikely to make more than a small contribution to the stability of the molecule. The presence of

TABLE XII

TS OF FASCIA FROM RHEUMATOID AND OTHER “COLLAGEN" DISEASES BEFORE AND AFTER 2M SALICYLATE

\begin{tabular}{|c|c|c|c|c|c|c|c|c|c|}
\hline \multirow{2}{*}{ Disease } & & \multirow{2}{*}{$\begin{array}{c}\text { Age } \\
\text { Group } \\
\text { (yrs) }\end{array}$} & \multirow{2}{*}{$\begin{array}{c}\text { No. } \\
\text { of } \\
\text { Cases }\end{array}$} & \multicolumn{2}{|c|}{$\mathrm{Ts}_{1}$} & \multicolumn{2}{|c|}{$T_{s_{2}}$} & \multicolumn{2}{|c|}{ Ts $s_{1}$ after Salicylate } \\
\hline & & & & Mean & Range & Mean & Range & Mean & Range \\
\hline Rheumatoid Arthritis & . & $\begin{array}{c}0-14 \\
26-44 \\
45 \text { and Over }\end{array}$ & $\begin{array}{l}4 \\
2 \\
6\end{array}$ & $\begin{array}{l}58 \\
58 \cdot 5 \\
59\end{array}$ & $\begin{array}{l}57-59 \\
58-59 \\
57-62\end{array}$ & $\begin{array}{l}66 \\
66 \\
67\end{array}$ & $\begin{array}{l}62-71 \\
65-67 \\
66-68\end{array}$ & $\begin{array}{l}29 \\
30 \\
31 \cdot 5\end{array}$ & $\begin{array}{l}28-30 \\
27-33 \\
28-34\end{array}$ \\
\hline Rheumatic Fever ... & $\ldots$ & $\begin{array}{l}13 \\
23\end{array}$ & $\begin{array}{l}1 \\
1\end{array}$ & $\begin{array}{l}58 \\
56\end{array}$ & - & $\begin{array}{l}62 \\
72\end{array}$ & - & $\begin{array}{l}33 \\
37\end{array}$ & - \\
\hline Dermatomyositis .. & $\cdots$ & 4 & 1 & 58 & - & 67 & - & 33 & - \\
\hline Periarteritis nodosa & $\ldots$ & 63 & 1 & 60 & - & 67 & 一 & 39 & - \\
\hline
\end{tabular}


an irreducible minimum of 0.5 per cent. polysaccharide in even the purest preparation of collagen suggests an important role for these substances as cementing or stabilizing agents. Jackson (1953), in particular, has emphasized the importance of such substances (e.g. chondroitin sulphate). The marked reduction in Ts of rat tail tendon (Jackson, 1954) following treatment with hyaluronidase or following oxidation with periodate which he observed strongly supports this hypothesis. We, however, have completely failed to confirm these results in similar experiments. The reduction of Ts of $12^{\circ} \mathrm{C}$. following treatment with hyaluronidase was less than that observed when similar material was treated in the buffer alone (pH 5.2). Similarly, the marked reduction observed in Ts after periodate treatment was no greater than that of the control material in the buffer alone at $\mathrm{pH} 4 \cdot 0$. In view of the recent report of Meyer, Davidson, Linker, and Hoffman (1956) that the chondroitin sulphate present in tendon is predominantly Type $\mathbf{B}$, i.e. the variety which contains iduronic acid and is insensitive to testicular hyaluronidase, it is not surprising that the effect of this enzyme is no greater than the buffer alone. The role of the mucopolysaccharides has also been questioned by Courts (personal communication). In his study of the collagen-gelatin transformation, he has shown that, during the liming process, considerable quantities of polysaccharides are removed, but, in the alternative process of acid pretreatment, which also facilitates the transformation to about the same degree, the whole of the mucopolysaccharide remains behind. This, as Courts points out, does not necessarily exclude the polysaccharide from playing a stabilizing role, since it is conceivable that the acid pretreatment might only disrupt one end of the hypothetical polysaccharide bridge.

Comparison of Tables I and II shows an apparent difference in response between human and other mammalian collagen to acid buffers at pH 4. This however, is probably not due to the difference in species but to the different nature of the buffers used. Acetate is known to possess a considerable lyotropic effect, presumably by virtue of its power to rupture hydrogen bonds (Gustavson, 1943).

With few exceptions, the effect of hydrogen bond breakers on Ts is confined to its influence on the temperature at which shrinkage begins, but has little effect upon the upper limit of Ts. This suggests either that the bonds responsible for stability at the higher temperatures are not hydrogen bonds, or that they are more concentrated in these more resistant regions. They are, nevertheless, moderately thermolabile, since they are apparently disrupted at between $60^{\circ}$ and $70^{\circ} \mathrm{C}$. Failure of extraction with phosphate buffer at $\mathrm{pH} 7$, or citrate buffer at $\mathrm{pH} 4$, to reduce the Ts (Table II) excludes both the alkali soluble and acid soluble forms of collagen fron the group of important stabilizing agents. Extractions with strong alkali reduced not only the $\mathrm{Ts}_{1}$ but also the $\mathrm{Ts}_{2}$, indicating that the bonds responsible for the upper limit of Ts are here also affected in addition to the rupture of hydrogen bonds. It is especially interesting in this regard to note that such treatment extracts a significant proportion of the mucopolysaccharides (Consden and Bird, 1954; Bird and Consden, 1955; Bowes, Elliott, and Moss, 1956) initially present, though it must be admitted that rupture of peptide bonds and loss of amide nitrogen also result from this treatment. The swelling which the tissue undergoes as a result of such strong alkaline treatment far exceeds that which occurs even with the most powerful hydrogen bond breakers, which may be regarded as further evidence for the disruption of other restricting bonds (Bowes and Kenten, 1950).

Effect on Shrink Temperature of Pretreatment with Salicylate.-The potent effect of salicylates on Ts has already been described by Lennox (1949) on sheep skin. He carried out his Ts estimations in solutions of salicylate so that his results are not comparable to ours in which the tissue was thoroughly washed after salicylate treatment and the Ts determined in saline. In the single experiment in which we determined the $T s$ in solutions of salicylates, our results were similar to his. The bulk of previous work on the influence of lyotropic agents on collagen has been carried out using hide powder. It is now appreciated that results with hide powder cannot necessarily be extrapolated to native collagen, since considerable denaturation occurs in the process of producing the powder. The different hydrogen bond breakers vary enormously in their ability to reduce the Ts in equi-molar solutions. In general, those which disrupt the hydrogen bonds by offering a competing hydrogen atom are more potent than those which are hydrogen acceptors.

The swelling of collagen after treatment with $2 \mathrm{M}$ salicylate is not comparable to that which occurs in strong alkali. The latter is almost entirely due to the uptake of water, but the swelling in salicylate is entirely due to the uptake of salicylate itself as is shown in Table VII, where the water content, expressed as a percentage of the wet salicylate-free tissue, is almost unchanged. The retention of salicylate up to as much as 40 per cent. of the initial dry weight, even after prolonged washing in distilled water, is noteworthy. The lowering effect of salicylate treatment on the Ts 
is, however, not to be attributed to this presence of salicylate, since equally low shrink temperatures are obtained after almost complete removal of the salicylate by weak bicarbonate (Table VIII).

The apparent lack of effect of pretreatment with $\mathrm{CaCl}_{2}$ on the Ts (Table VI) contrasts with the known lyotropic effect of this salt on hide powder (Gustavson, 1956c). Here again the difference is probably attributable to the denaturation which the collagen has undergone in the production of hide powder.

Further evidence favouring the presence of two distinct types of stabilizing bonds in the collagen molecule may be deduced from the behaviour of acid soluble collagen in salicylate. Since acid soluble collagen has $\mathrm{Ts}_{2}$ of only $45^{\circ} \mathrm{C}$., it may be inferred from what we have said before that the bonding is entirely of the hydrogen type. The complete solubility of this form of collagen in salicylate is in conformity with this view. Failure to reprecipitate such a solution of acid soluble collagen by dialysis and alkalinization shows further that the disruption of the hydrogen bonds brought about by the salicylate is irreversible.

Shrinkage Temperature in Salicylate Solutions.The Ts undergoes much greater reduction when carried out in the presence of salicylate (Fig. 2) than when treated for 4 days in the same solution and thoroughly washed before determining the Ts in saline. Still more remarkable is the effect of the presence of relatively low concentrations of salicylate on the Ts.2, which, it will be recalled, is scarcely affected by pretreatment with high concentrations of salicylate when the Ts is subsequently determined in saline. It is difficult to explain these results, but they suggest that the bonds responsible for the stability at higher temperatures only become accessible to the salicylate molecules when the structure of the collagen fibrils is itself disorganized by the steric changes that underline the shrinkage occurring at lower temperatures. This is borne out by the remarkable coincidence of the two curves showing the relationship of $\mathrm{Ts}_{2}$ to molarity of salicylate when the determination is made after 5 days or immediately. The inference from this coincidence is that the bonds responsible for stability at the higher temperature remain intact during the whole 5 days of immersion and only become affected during the process of shrinkage in the presence of salicylates.

Effect of Salicylate on Tryptic Digestibility.-The tryptic digestibility of both collagen and noncollagen protein is affected by exposure to salicylate, whereas only about half the non-collagen protein originally present is digestible by trypsin without salicylate pretreatment. $1 \mathrm{M}$ salicylate for 4 days $\frac{\prod_{0}}{\widehat{0}}$ renders the whole of the non-collagen protein trypsin $\frac{5}{3}$ digestible, although the collagen itself still remains $\square$ almost completely resistant. The resistance of native collagen to tryptic digestion is unlikely, therefore, to be due to the presence of a non- $\stackrel{5}{+}$ collagenous protein-cementing substance. Treat- 을 ment with $2 \mathrm{M}$ salicylate results in about half of the $\frac{\overline{\bar{O}}}{\overline{0}}$ collagen becoming digestible by trypsin. Deter- $\frac{\sigma}{\sigma}$ mination of the Ts of the residue shows, however, $\unrhd$ that it is not the whole of the fraction with low Ts i that is digested, since the Ts is virtually unchanged. $\vec{\circ}$ That hydrogen bond breakers alone can render native collagen, at least in part, digestible by tryptic enzymes suggests a possible mechanism by which mature collagen fibres might be removed in vivo, under both physiological and pathological conditions.

Variation with Age of Shrinkage Temperature and of the Response of Ts to Salicylate.-Native collagen, at least as judged by its Ts, is in its least stable form during foetal life. Increasing stability, as shown by the rising Ts with age (Table IX), could be attributed either to an increase in number of hydrogen bonds, or to the development of other types of internal bonding. Failure to reduce the $\mathrm{Ts}_{1}$ of mature adult tissue by immersion in salis cylate to the level obtainable with foetal tissue suggests that the bonds responsible for the increased stability at the later age are not hydrogen bonds. As we have pointed out above, however, a similar result would be obtained if the extra hydrogen bonds were inaccessible to the salicylate. The results obtained when shrinkage is determined in the presence of salicylate, the $T s_{1}$ in these circumstances falling to the same level as that of foetal tissue, does suggest that the bonds affected are indeed hydrogen bonds, but less accessible than those present in young unshrunk tissue. A possible way by which such extra hydrogen bonds could arise is between the sites occupied by mucopolysaccharides, as these are progressively lost with increasing age. The evidence provided by $x$-ray diffraction (Hartmann, Gattow, and Fricke, 1957) of increasing orientation of collagen with increasing age is compatible with this view. The apparent break in the curve showing rise of Ts with age between the ages of 15 and 44 years corresponds roughly with the period of active sex life. The relationship of this to hormonal control needs no emphasis.

Shrinkage Temperature of Uterine Collagen.The anomalous position of uterine collagen is presumably related to its cyclic activity and this is in part confirmed by the rise in $\mathrm{Ts}_{\mathbf{1}}$ which follows 
the menopause. The speed with which large quantities of collagen disappear in the puerperal uterus makes it a subject of special interest, since it contrasts so markedly with the stability of adult collagen elsewhere. Although we have not found it any more readily digestible by trypsin than other native collagen, its initially lower $\mathrm{Ts}_{\mathbf{1}}$ must render it more sensitive to the mechanisms in vivo which are presumably available to solubilize and remove unwanted collagen.

Fluorescence of Collagen.-It is well known that collagen fluoresces in ultra-violet light. Of the specimens of mammalian collagen which we have examined, the only two tissues which failed to give this fluorescence were pre-menopausal uterine and foetal collagen. The acquisition of the adult type of fluorescence seems to appear in non-uterine collagen sometime between the ages of 11 months and 4 years. In the uterus the appearance of similar fluorescence occurs approximately at the menopause. The nature of the fluorescent material and its significance are still obscure.

Shrinkage Temperature of Collagen from Rheumatoid Nodules.-Histological study of rheumatoid nodules shows evidence of fragmentation, fibrillation, and disappearance of collagen (Glynn and Reading, 1956), which is supported by more modern methods of examination (Kellgren, 1952). This loss of collagen must be the result of enzymatic activity and, at the pH obtaining in the tissues, the only known proteolytic enzymes available are tryptic in type, to which, as we know, unaltered collagen is highly resistant. This of necessity implies that, before its removal by such enzymes, the collagen must undergo some fundamental change which could most readily be detected as a fall in Ts. This, as we have shown in the experimental section of this paper, can be detected by the use of a micromethod. From what is known of the structure of collagen which renders it resistant to tryptic enzymes, it is apparent that some fundamental change in the internal structure is essential as a preliminary to enzymatic removal. This could conceivably be brought about by local concentrations of substances capable of disrupting the hydrogen bonds.

\section{Summary}

(1) The shrinkage temperature and digestibility by trypsin of human and animal collagen were studied before and after various treatments.

(2) Periodate and hyaluronidase had no greater effect on the shrink temperature than did the buffers in which the treatment was given. Acetate buffer at $\mathrm{pH} 4.0$ or $\mathrm{N} / 5 \mathrm{KOH}$ lowered the shrink tempera- ture, but citrate and phosphate buffers at $\mathrm{pH} 4 \cdot 0$ and 7.0 respectively were without effect.

(3) When tissues were treated with hydrogen bond breakers and then washed, there was a considerable lowering of shrink temperature. This effect was greater when shrinkage was determined in solutions of hydrogen bond breakers. Of the reagents tested, hydrogen donors were more effective than hydrogen acceptors; salicylates caused the greatest lowering. The reduction in shrink temperature was shown to be independent of any induced swelling.

(4) Pretreatment with $1 \mathrm{M}$ salicylate followed by trypsin removed virtually all the non-collagen protein but very little of the collagen. With $2 \mathrm{M}$ salicylate followed by trypsin, nearly half the collagen was digested. No collagen was extracted by the salicylate alone.

(5) Human collagen from older subjects had a significantly higher shrink temperature than that from younger subjects, but foetal collagen showed no such variation with foetal age.

(6) Uterine collagen had a shrink temperature similar to that of foetal or very young collagen.

(7) Collagen usually fluoresces strongly in ultraviolet light. Foetal collagen and pre-menopausal uterine collagen do not fluoresce, but uterine collagen acquires fluorescence after the menopause.

(8) Collagen from three rheumatoid nodules fluoresced poorly in ultra-violet light. The shrinkage temperature was distinctly lower than that of normal collagen.

(9) The factors responsible for stabilizing collagen are discussed together with some biological implications.

One of us (P.B.) is in receipt of a grant from the Medical Research Council. We thank Mr. D. Maxwell and Mr. F. H. H. Finlaison for supplying us with uterine material and Miss B. M. Haines, B.Sc., for introducing us to the micromethod of measuring shrink temperatures.

\section{REFERENCES}

Banga, I., Baló, J., and Szabó, D. (1956). Acta physiol. Acad. Sci. hung., 9, 6i.

Beet, A. E. (1955). Nature (Lond.), 175, 513.

Bird, R., and Consden, R. (1955). Biochem. J., 60, ix.

Bowes, J. H., Elliott, R. G., and Moss, J. A. (1955). Ibid., 61, 143.

Bowes, J. H., Elliott, R. G., and , 63, 1 P.

- Kenten, R. H. (1950). Ibid., 46, 1

Consden, R., and Bird, R. (1954). Nature (Lond.), 173, 996.

Glynn, L. E., and Reading, C. A. (1956). 7 Colloq. der Gesells. f. physiol. Chem., 54. Springer-Verlag, Berlin.

Gustavson, K. H. (1943). Svensk Kem. T., 55, 191.

(1956a). "The Chemistry and Reactivity of Collagen", p. 132. Acad Press Inc., New York.

(1956b). Ibid., p. 231.

- (1956b). Ibid., p. 231 .

Harkness, M. L. R., and Harkness, R. D. (1954). J. Physiol. (Lond.), 123, 492 .

Hartmann, von F., Gattow, G., and Fricke, R. (1957). Z. Rheumaforsch., 16, 243.

Jackson, D. S. (1953). In J. T. Randall and G. F. Jackson, “Nature and Structure of Collagen", p. 177. Butterworth, London. - (1954). Biochem. J., 56, 699. 
Kellgren, J. H. (1952). Brit. med. J., 1, 1093

Ball, J.. Astbury, W. T., Reed, R., and Beighton, E. (1951). Nature (Lond.), 168, 493

Lennox, F. G. (1949). Biochim. biophys. Acta, 3, 170

Meyer, K.. Davidson, E., Linker, A... and Hoffman, P. (1956). Ibid., 21, 506.

Neuman, R. E., and Logan; M. A. (1950). J. biol. Chem., 184, 299

Partridge, S. M. (1948). Biochem. J.. 43, 387

Trinder, P. (1954). Ihid. 57, 301.

Observations sur la température de contraction du collagène et ses variations selon l'âge et la maladie

\section{RÉSUMÉ}

(1) On a étudié la température de contraction et la digestibilité par la trypsine du collagène humain et animal avant et après certains traitements.

(2) L'effet du périodate et de l'hyaluronidase sur la température de contraction n'était pas supérieur à celui des tampons usés dans le traitement. Le tampon d'acétate au $\mathrm{pH} 4.0$ ou $\mathrm{KOH}$ à $\mathrm{N} / 5$ faisait baisser la température de contraction, mais les tampons de citrate et de phosphate au pH 4.0 et 7.0 respectivement n'avaient aucun effet.

(3) Quand on traitait les tissus par des briseurs de liaison hydrogénés et on les lavait, il s'y produisait une baisse considérable de la température de contraction. Cet effet était plus accentué lorsqu'on déterminait la contraction dans des solutions de briseurs de liaison hydrogénés. Parmi les réactifs essayés, les donneurs d'hydrogène étaient plus efficaces que les recepteurs d'hydrogène; les salicylates provoquaient la baisse la plus accentuée. La réduction de la température de contraction était indépendante de tout gonflement provoqué.

(4) Le traitement préalable par le salicylate $1 \mathrm{M}$, suivi de trypsine, enlevait virtuellement toute la protéine noncollagène, mais très peu de collagène. Avec la salicylate $2 \mathrm{M}$, suivi de trypsine, presque tout le collagène se trouvait digéré. On ne pouvait pas extraire du collagène avec le salicylate seul.

(5) Le collagène humain des sujets âgés avait une température de contraction appréciablement plus élevée que celui des sujets plus jeunes, mais le collagène foetal n'accusait pas de telles variations selon l'âge foetal.

(6) La température de contraction du collagène utérin était similaire à celle du collagène foetal ou très jeune.

(7) Le collagène est généralement fluorescent à la lumière ultra-violette. Le collagène foetal et utérin pré-ménopausique ne l'est pas, mais le collagène utérin devient fluorescent après la ménopause.

(8) La fluorescence à la lumière ultra-violette du collagène provenant de nodules rhumatismaux est faible: sa température de contraction est nettement inférieure à celle du collagène normal.

(9) On discute les facteurs intervenant dans la stabilisation du collagène ainsi que les implications biologiques.

Observaciones sobre la temperatura de contracción del $\overrightarrow{\overline{\vec{C}}}$ colágeno y sus variaciones según la edad y la enfermedad

\section{SUMARIO}

(1) Se estudió la temperatura de contracción y la digestibilidad por la tripsina del colágeno humano y animal antes y después de ciertos tratamientos.

(2) El efecto del periodato y de la hialuronidasa sobre la temperatura de contracción no fué superior al de los ${ }^{\infty}$ tapones empleados en el tratamiento. El tapón de $\overrightarrow{0}$ acetato al $\mathrm{pH} 4.0$ o $\mathrm{KOH} \mathrm{N} / 5$ hacía bajar la temperatura: de contracción, pero los tapones de citrato y de fosfato $\vec{\omega}$ al pH 4 y 7 respectivamente no tuvieron efecto alguno.

(3) Cuando se trataba los tejidos con quebradores hidrogenados de lazos ye se los lavaba, se obtenía una baja considerable de la temperatura de contracción. $\rightarrow$ Este efecto fué más marcado al determinar la contracción. en soluciones de quebradores hidrogenados de lazos. $N$ Entre los reactivos empleados, los dadores de hidrógeno $\overrightarrow{0}$ fueron más eficaces que los aceptadores de hidrógeno: los salicilatos provocaban la baja la más acentuada. 윽 La reducción de la temperatura de contracción fué independiente de toda tumefacción provocada.

(4) El tratamiento previo con el salicilato $1 \mathrm{M}$, seguido de tripsina, eliminaba virtualmente toda la proteina non- $\overparen{D}$ colágena, pero muy poco de colágeno. Con el salicilato $\overrightarrow{0}$ $2 \mathrm{M}$, seguido de tripsina, casi todo el colágeno se vęav digerido. No se pudo extraer colágeno alguno con Q l. salicilato solo.

(5) La temperatura de contracción del coláge humano de sujetos de edad avanzada fué apreciadamerțe mayor que la de sujetos jóvenes, pero no hubo tales variaciones según la edad en el colágeno fetal.

(6) La temperatura de contracción del colágenoळి uterino fué similar a la del colágeno fetal o muy joven.

(7) $\mathrm{El}$ colágeno es generalmente fluorescente a la $\overline{\widehat{O}}$ luz ultra-violeta. El colágeno fetal y uterino pre-3 menopáusico no lo es, pero el colágeno uterino se vuelve fluorescente despuès de la menopausia.

(8) La fluorescencia a la luz ultra-violeta del colágeno de los nódulos reumáticos es muy débil. La tempera- 용 tura de contracción es marcadamente más baja que la del. colágeno normal.

(9) Se discuten los factores interviniendo en la estabi lización de colágeno así como las implicaciones biológicas. 